The Japanese Journal of Psychology

1975, Vol 46, No. 1, 19-28

\title{
観察学習の反応㥞式に関す万発達的研究
}

\author{
広島大学

$\begin{array}{cccc} & \text { 祐 } & \text { 宗 } & \text { 省 }{ }^{2} \\ \text { 琉球大学 } & \text { 長 崎大学 } \\ \text { 井上 } & \text { 厚 } & \text { 平井誠 也 } \\ \text { 広島大学 } & \text { 広島大学 } \\ \text { 利 島 } & \text { 保 } & \text { 羽生義 正 }\end{array}$

\section{A DEVELOPMENTAL STUDY OF OBSERVATIONAL LEARNING MODES}

\section{SEISOH SUKEMUNE}

Hiroshima University

\author{
ATSUHI INOUE \\ University of the Ryukyus \\ TAMOTSU TOSHIMA \\ Hiroshima University
}

\author{
SEIYA HIRAI \\ Nagasaki University \\ YOSHIMASA HABU \\ Hiroshima University
}

\begin{abstract}
72 preschoolers and 72 school children observed the original discrimination of nonreversal shift (NRS) followed by 14 NRS trials by themselves. The observational trials were 10 or 30 in each age group. The correct $(O)$ or incorrect $(x)$ responses on the $1 \mathrm{st}$ (unchanged pair) and the 2 nd (changed pair) trials of NRS were mainly measured. In preschoolers, both dependent observational-learning mode $(O-X$ responses : DOL) and independent observational-learning mode (O-O and $x-x:$ IOL) were found, but no observational-trial effects on the modes were found. In school children, DOL occurred significantly more than IOL in both groups, and the observational-trial effect was also found. Subproblem analyses suggested that the $O-X$ responses were indeed the "dependent" mode rather than the "independent" one.
\end{abstract}

われわれはすでに, 2 選択同時弁別学習事態（祐宗・ 利島，1973）ならびに選択移行学習事態（利島・祐宗， 1973）を用いた幼児の観察学習滘する関す験的研究に抹 いて，観察者（以下 $\mathrm{OB}$ 之略す）の之った反応様式を分 析した。.その結果，モデル(以下 MOと略す)の反応を

1 本研究は，第一筆者の昭和 48 年度文部省科学研究 費補助金（一般研究 C，課題番号 851034）ならびに同 筆者の昭和 49 年度同補助金 (一般研究 C, 課題番号 951031）による研究の一部である。

2 本実験の実施にめたり，被験者と実験室を提供して 下さった長崎市住吉保育園ならびに広島市祇園小学校 々, モデルの学生に対し厚く感謝の意を表します。
単純・非媒介的飞観察し反応する様式と，MO の反応を 認知・媒介的潅察し反応する様式の $2 つ か ゙$ 存在するこ とを見出した、したがって観察学習は, 単純な $\mathrm{S}-\mathrm{R}$ 強 化理論, 媒介理論または認知理論のうち、いずれかの理 論の枠組の中での及説明されらるものではなくて，ある 特定の条件下では異なるメカニズムによる観察学習の反 応様式が共に存在することがわかった。

上述した観察学習の 2 つの反応様式は，共に幼児を被 験者とした升別学習事態で見出されたるのである. 一 方，知的な面でより発達した段階にいる児童を対象とす る弁別学習事態飞物いては，幼児の場合とは異なり，単 純・非媒介的飞観察し反応する㥞式の出現は減少し, 反 
面認知・媒介的に観察し反忘する様式が優位を占めるで あろらといらことが期待される。

そこで本研究では, 年龄を1つの要因とし，さらに観 察試行数す要因として組み入れ 2 次元 2 価の非逆転移 行学習（以下 NRS と略す）の範例に準拠した事態で, この種の問題が取り扱われる. 一般的な 2 次元 2 価の NRS 事態は，たとえば本実験で用いられているように， 大円 $(+)$ と小三角形 $(-)$ の対と大三角形 $(+)$ と小円 $(-)$ の対の 2 つをンダムに提示し，学習規準に到達するま で試行をかさねる，この場合，形は異なっていても大き い方が(十)で小さい方が(一)といらことが学習される. 次いで大円 $(+)$ と小三角形 $(-)$ の対（正負の関係は変化 していない）と大三角形 (一) と小円 $(+)$ の対（正負の関 係は変化している) の2つをランダムに提示し，学習規 準に到達するまで試行をかさねる。この場合には，大き さは異なっていて子円が(十)で三角形が(一)ということ が学習される。すなわら，大 $(+) \rightarrow$ 円 $(+), 大(+) \rightarrow 三$ 角形 $(+)$, 小 $(+) \rightarrow$ 円 $(+)$, 小 $(t) \rightarrow$ 三角形 $(+)$, 円 $(+) \rightarrow 大(t)$, 円 $(+) \rightarrow$ 小 $(+)$, 三角形 $(+) \rightarrow 大(+)$, 三角形 $(+) \rightarrow$ 小 $(+)$ の 8 つ移行条件がある. 同じ次元 内での移行 $(大(t) \rightarrow$ 小 $(+)$, 小 $(+) \rightarrow 大(t)$, 円 $(+)$ $\rightarrow$ 三角形 $(+)$, 三角形 $(+) \rightarrow$ 円 $(+))$ は逆転移行といわ れている。

本実験においてとくにこの事態を用いた理由は，先行 学習を観察し，その後ひさつついてOBに課せられるNRS 過程（とくにその初期段階での試行）に扮いて，2つの 弁別刺激対のそれぞれに対する OB の反応を類別しさら にそれらの反応様式がその後の NRS 過程の OB の独自 学習 に蛙よぼす効果を詳細に分析することによって, 本実験で問題としてとりあげられる反応様式の類別の適 切さを一層明瞭な形で確かめることができると考えたか らである、本実験ではこれまでの研究法といくらか異な り, OBK要求される反応は, 観察する MO の反応と全 く同じ反応ではなくて，MO の反応を観察しそれのいわ ば転移として OB 自身が新しい反応を行なうことであ る、したがって，それをみるためには NRS の過程をと らえるのが適切であるように思われる，本実験では， 2 次元 2 価の刺激対を用いた先行弁別後の NRS 事態であ るから，OB 自身が反応する段階では，2つの刺激対のう ら, 当然一方の対の正負関係は変化せず，MOに対して 与えられていた正負関係と同一である（非変化対）が, 反面他方の対は正負関係が逆になる(変化対) 事態であ る. OB の行なら NRS の第 1 試行には非変化対を，第

3 独自学習とい5用語は，一般に統制群としての非観 察群の反応に対するものである。しかし，本研究では NRS の第 3 試行以後に拈いて OB 自身の行なった反応 の正・誤に基づく OBの学習過程に関連した用語として 用いる.
2 試行には变化対を提示した場合, 第1 試行と第 2 試行 に持ける正反応（以下○と略す）と誤反応（以下 $\times$ と略 す) の関係としては，○-×，○-○，×-×， ×-○の 4 通りのものがある。この場合 ○一×を示した $\mathrm{OB}$ は, 非 変化対が提示された第1試行では正反応を示し, そして 変化対が提示された第 2 試行では說反応を示し, 先行学 習 (観察時) に扣いて 2 つ刺激対に対してMOが行な った正反応を十分観察しその効果があらわれたことを示 している。すなわら，このような反応を示す OB は, 2 つの刺激対をいわば “依存的”に観察し反応する様式 （以下 DOL 反応椂式と略す）に基ついて反応したと考 えられる. これに対して○一○，×ーメは，いずれか一方 の刺激対の正負関係のみを観察しその効果があらわれた ことを示している.すなわち，このような反応を示す OB は，2つの刺激対をいわば “独立的”に観察し反応 する様式（以下 IOL 反応様式と略す）に基づいて反応 したと考えられる。な括，メー○は 2 つの刺激対のいず れをる OB 自身の反応にあらわれるほど十分に観察して いなかったことを示していると考兄られる。本研究に就 いて，DOL 反応様式と IOL 反応様式の類別が，NRS の 第 1 試行之第 2 試行の正・誤反応の関係, すなわち $\bigcirc-$ $\times, \bigcirc-O, \times-\times$ の面から決定された理由は, NRSの 第 3 試行以後は OB の独自学習の効果が, 多かれ少なか: れ入ってくると思われたからである.したがって，実験 事態によって多少の違いはあるであろらが，観察学習の 直接の効果を厳密にとらえるためには, 本研究のように できるだけ OB の行なら初期の反応を中心にみていくの が適切であると考えられる。

これまでの研究（祐宗・利島, 1973 ; 利島・祐宗, 1973）と本研究とでは，実験事態が相互に異なり，した がって手続き上，反応様式のとらえ方も翼なっている． したがってこれまでに見出されてきた単純・非媒介的反 応様式がここでの IOL 反応様式に，そして認知・媒介 的反応様式がここでの DOL 反応様式にそれぞれそのま ま直接的に対忘するものではないとしても，本実験での DOL 反応様式が多分に認知学習的な面をもって拉り, そして IOL 反応様式が多分に単純・非認知的な面をも っているといらことが考学らる.

本研究とは事態のやや異なる利島・祐宗（1973）の研 究結果から, 幼児では観察試行数が少ない場合, IOL 反 応様式 $(\bigcirc-O, x-x)$ と DOL 反応様式 $(\bigcirc-x)$ の 2 つの反応様式がほぼ同じ比率で出現するであろう。一 方, 観察試行数が多い場合についてみると, 観察期間が 長くそのため各刺激対-報酬関係が依存的に学習される ため, IOL 反応様式よりも DOL 反応様式がより多くあ らわれるであろらということが仮説される。したがっ て, 本研究の第 1 の主要な目的はこの仮説を検証するこ とである. 第 2 の主要な目的は, 上述したように認知・ 
TABLE 1

Summary of experimental design following nonreversal shift discrimination

\begin{tabular}{|c|c|c|c|c|c|c|c|}
\hline & \multirow{2}{*}{\multicolumn{2}{|c|}{ Group }} & \multirow{2}{*}{$N$} & \multicolumn{2}{|r|}{$\mathrm{CA}$} & \multirow{2}{*}{ Original discrimination } & \multirow{2}{*}{$\begin{array}{l}\text { Nonreversal shift } \\
\text { discrimination } \\
\text { (test trials) }\end{array}$} \\
\hline & & & & $\bar{X}$ & range & & \\
\hline \multirow{2}{*}{ MO } & \multirow{2}{*}{\multicolumn{2}{|c|}{$\begin{array}{l}\text { I } \\
\text { II }\end{array}$}} & \multirow{2}{*}{\multicolumn{2}{|c|}{$\begin{array}{l}\text { (8 trained students } \\
\text { models) }\end{array}$}} & \multirow{2}{*}{ served as } & 10 demonstrational trials & \\
\hline & & & & & & 30 demonstrational trials & \\
\hline \multirow{3}{*}{$\mathrm{OB}$} & \multirow{3}{*}{$\begin{array}{c}\text { Pre- } \\
\text { school } \\
\text { children }\end{array}$} & I & $24\left\{\begin{array}{l}\text { Boy : } 12 \\
\text { Girl }: 12\end{array}\right.$ & $5: 06$ & $5: 00-6: 01$ & 10 observational trials & 14 nonreversal shift trials \\
\hline & & II & $24\left\{\begin{array}{l}\text { Boy }: 12 \\
\text { Girl }: 12\end{array}\right.$ & $5: 06$ & $4: 11-5: 11$ & 30 observational trials & 14 nonreversal shift trials \\
\hline & & Controls & $24\left\{\begin{array}{l}\text { Boy : } 12 \\
\text { Girl }: 12\end{array}\right.$ & $5: 05$ & $5: 00-5: 11$ & & $\begin{array}{l}\text { the same } 14 \text { trials as } \\
\text { an OB's shift trials }\end{array}$ \\
\hline \multirow{3}{*}{$O B$} & \multirow{3}{*}{$\begin{array}{c}\text { Primary } \\
\text { school } \\
\text { children }\end{array}$} & I & $24\left\{\begin{array}{l}\text { Boy }: 11 \\
\text { Girl }: 13\end{array}\right.$ & $8: 11$ & $8: 01-9: 10$ & 10 observational trials & 14 nonreversal shift trials \\
\hline & & II & $24\left\{\begin{array}{l}\text { Boy : } 14 \\
\text { Girl }: 10\end{array}\right.$ & $8: 11$ & $7: 11-9: 10$ & 30 observational trials & 14 nonreversal shift trials \\
\hline & & Controls & $24\left\{\begin{array}{l}\text { Boy : } 11 \\
\text { Girl : } 13\end{array}\right.$ & $8: 11$ & $8: 00-9: 10$ & & $\begin{array}{l}\text { the same } 14 \text { trials as } \\
\text { an OB's shift trials }\end{array}$ \\
\hline
\end{tabular}

Legend : MO represents a model. OB represents an observer.

媒介的に観察し反応する様式が優位を占める児童では， 観察試行数が少ない場合でも多い場合でも IOL 反応様 式よりるDOL 反応様式がより多くあらわれるが，とく に多い場合についてみると，観察期間が長くそのため各 刺激対一報酬関係が一層依存的に学習されるため, IOL 反応様式は極めて少なく、ほとんと DOL 反応様式の及 があらわれるであろうという仮説を検証することである. さらに，先にす述べたように，NRS の全過程を変化対 と非変化対に分けて正反応率をみる下位問題分析を行な らことによって, 両反応様式の類別の適切さならびに両 反応様式のその後の独自学習に拉よぼす効果がより明ら かにされるであろう、すなわち，とくに第 2 対試行に拉 いて DOL の非変化対に対する正反応率が第 1 対試行の それより減少する傾向がみられるなら，それは第 1 対試 行に特ける変化対に対する反応の結果（ここでは当然誤 反応となる）に影響をうけたことを意味し，したがっ

Original discrimination Nonreversal shift discrimination (test trials)

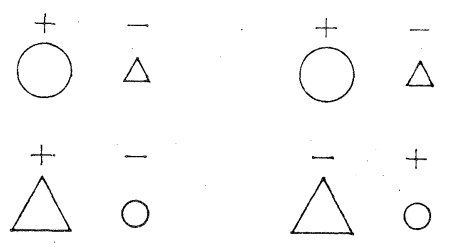

FIG. 1. An example of nonreversal shift discrimination problems.
て DOL 反応様式を“依存的”なるのだと類別すること が適切であるとい古よう. 第 3 対試行以後に拉いてもこ のような傾向はいく分持続するであろらが，漸次両対に 対する正反応率は上昇し両者の開きは小さくなるであろ 万. 一方 IOL 反応様式では，この点については一貫し た傾向は見出されず，したがって両対の開きは小さく， 両対に対する正反応率は漸次上昇するであろう．上記の 仮説を検討するのが第 3 の目的である.

\section{方 法}

被験者 長崎市内の幼児で, この種の実験に未経験な 72 名と広島市内の小学校 2,3 年生で, 同様に未経験な 72 名の, 合計 144 名を被験者とした (Table 1 参照). な拓広島大学・長崎大学の学生 8 名が MO として参加し た.

弁別刺激対と装置 弁別刺激としては, すべて赤色 （日本色研の色紙で, 色相 1 , 彩度 9 , 明度 15) で 1 辺 $11.5 \mathrm{~cm}$ と $5 \mathrm{~cm}$ の大小 2 個の正三角形と, 直径 10.5 $\mathrm{cm}$ と $5 \mathrm{~cm}$ の大小 2 個の円をそれぞれ白ケント紙に貼 りつけたるのが用いられた. 各刺激カードは, 広大幼研 式簡易型弁別学習実験装置を用いて提示された。この装 置では, ボタン押し反応のために，各刺激に対応する位 置に押しボタンが用意されている（祐宗, 1973 の Fig. 1 参照).

実験計画と手続き 実験者（以下 $E$ と略す）は $\mathrm{OB}$ を 誘道し，すでにそこに待機していた MO に対して, 次 の教示を与えた。“これからカードのあてっこ遊びをし 
TABLE 2

The number of $S$ s who made dependent observational-learning mode (DOL), independent observational-learning mode (IOL), and inadequate response (IAR) during nonreversal shift discrimination (test trials)

\begin{tabular}{|c|c|c|c|c|c|c|}
\hline \multirow{2}{*}{ Observational learning mode } & \multicolumn{3}{|c|}{ Primary school children } & \multicolumn{3}{|c|}{ Preschool children } \\
\hline & Group I & Group II & Controls & Group I & Group II & Controls \\
\hline $\begin{array}{l}\text { Dependent observational-learning mode } \\
\qquad(O-x)\end{array}$ & 15 & 20 & 2 & 10 & 9 & 1 \\
\hline $\begin{array}{l}\text { Independent observational-learning mode } \\
\qquad\left(\begin{array}{l}O-O) \\
(x-x)\end{array}\right.\end{array}$ & $\begin{array}{l}6 \\
(2) \\
(4)\end{array}$ & $\begin{array}{l}2 \\
(1) \\
(1)\end{array}$ & $\begin{array}{r}14 \\
2\end{array}$ & $\begin{array}{l}10 \\
(8) \\
(2)\end{array}$ & $\begin{array}{l}12 \\
(8) \\
(4)\end{array}$ & $\begin{array}{r}11 \\
9\end{array}$ \\
\hline $\begin{array}{l}\text { Inadequate response } \\
\qquad(x-O)\end{array}$ & 3 & 2 & 6 & 4 & 3 & 3 \\
\hline Total & 24 & 24 & 24 & 24 & 24 & 24 \\
\hline
\end{tabular}

Legend : $\bigcirc-\times$ represents a correct response on the first trial and an incorrect response on the second trial of nonreversal shift discrimination (test trials).

-O represents correct responses both on the first and the second trials of nonreversal shift discrimination (test trials).

$x-x$ represents incorrect responses both the first and the second trials of nonreversal shift discrimination (test trials).

$x-O$ represents an incorrect response on the first trial and a correct response on the second trial of nonreversal shift discrimination (test trials).

Note : The number of $S$ s in control groups in this table does not show each observational learning mode, but only shows correct-incorrect responses such as $\bigcirc-x, 0-0, \times-\times, \times-\bigcirc$ on the first and the second test trials, respectively.

ましょら・ここにカードが2枚でてきます。このうちど ららかがいつる ‘あたり’とさめられています。あり と思う方のボタンを押して下さい。あたっていれば・あ たり’といいます.その時にはランプがつきます.ちがっ

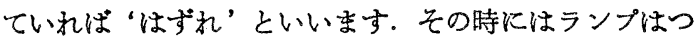
さません、いつる “あたり’といわれるよらにつづけて たくさんあてて下さい”. 次いで $E$ は OB に対して, “この人がすんだら，あなたに゙あやってもらいます. よく見ていて下さい”と教示した. 教示終了後すぐ MOの行なら連続正反応の示範に移った。 このとき用い られた刺激対は，形と大きさの 2 次元 2 価のあので, 三 角形，円，大，小をそれぞれ正刺激とする 4 つの条件が 設定された. 幼児と児童の両群は，さらに観察試行数が 10 回（第I群）と30回（第群）の2 群に分けられた. MOの示範試行が終ると，EはMOK対して“よくでき ました。あなたはこれで扎しまいにしましょら”と言 い, OB に対しては“よく見ていましたか。こんどはあ なたにやってあらいます。たくさんあてて下さい”と教 示しすぐ OB による NRS に移った。 NRS では, 正刺 激が大 $\rightarrow$ 円，大 大三角形，小 $\rightarrow$ 円，小 小三角形，円 $\rightarrow$ 大, 円 $\rightarrow$ 小, 三角形 $\rightarrow$ 大, 三角形 $\rightarrow$ 小の 8 つの条件が設 定され，各群とす各条件に 3 名宛ランダムに割りあてら
れた. 非変化対 (以下 1 と略す) と変化対（以下 2 と略 す）の提示順序は, $1,2,1,2,1,2,2,1,1,2,1,2,1,2$ で, 1 と 2 はそれぞれ 7 試行宛, 計 14 試行が実施された。 各対に括ける正刺激の左右の位置は通常のゲラマン系列 で提示された。な拉，観察をしないで，OBが行なう NRS と同じ試行のみが課せられる統制群が幼児・児童 ともに設けられた. 刺激対の提示の 1 例が Fig. 1 に; また実験計画の概要が Table 1 に示されている.

\section{結果}

NRS の第 1 試行 (非変化対) と第 2 試行 (変化対) に対する正反応 $(O)$ と誤反応 $(x)$ の関係から, DOL 反 応様式 $(O-x)$, IOL 反応様式 $(O-O, x-x)$, そのい ずれでもなく観察不十分なもの $(\times-○)$ の出現頻数（人 数）を幼児・児童とあ各実験群ごと，ならびにとれらに 対応する統制群に持ける出現頻数を示したるのが Table 2 である。

幼児全体では, DOL 反応様式 (19) と IOL 反応様式 （22）の雨者間には有意差がなかった $\left(\chi^{2}(1)=0.22\right)$. 幼 児の第群についてみると，DOL 反応様式 (9) と IOL 反応様式(12)の間には有意差がなかった $\left(\chi^{2}(1)=0.43\right)$. 第 I 群では IOL 反応様式も DOL 反応様式す共に出現 
頻数は10で有意差はなかった. 次に児童全体では, DOL 反応様式 (35) が IOL 反応様式 (8) より有意に多く $\left(\chi^{2}{ }_{(1)}\right.$ $=16.95, p<.001)$, 第I群でも DOL 反応様式 (20) が IOL 反応様式 (2) より有意に多い $\left(\chi^{2}{ }_{(1)}=14.73, p<\right.$ .001）が，また第I群でも DOL 反応様式 (15) と IOL 反応様式 (6) の間にも有意差が見出された $\left(\chi^{2}{ }_{(1)}=3.85\right.$, $p<.05)$.

次に, NRS の全 14 試行のらち, 最初に非変化対が提 示される試行（すなわち第1試行）と最初に変化対が提 示される試行（すなわち第 2 試行）を第 1 対試行とし, 以後同様の手続さで第 7 対試行までそれぞれ非変化対と

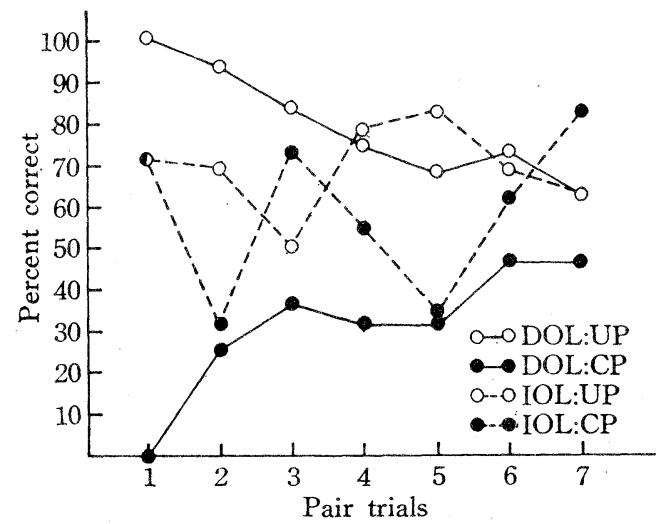

FIG. 2. Learning functions of preschool children showing both dependent observational-learning mode (DOL) and independent observational-learning mode (IOL) of NRS-changed and NRS-unchanged.

Note. UP : Unchanged pair. CP : Changed pair.

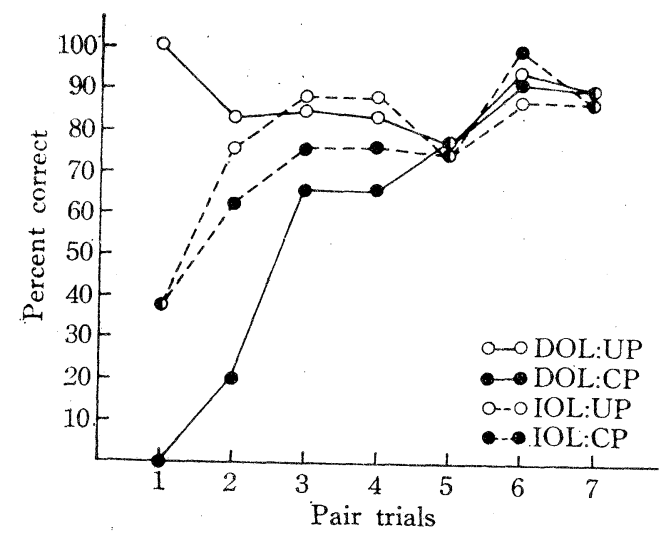

FIG. 3. Learning functions of primary school children showing both dependent observationallearning mode (DOL) and independent observationallearning mode (IOL) of NRS-changed and NRSunchanged.

Note. UP : Unchanged pair. CP : Changed pair.
変化対とに分けて正反広率を算出し，それを幼児・児童 とも DOL と IOL の両反応様式別に示したるのが Fig. 2 と Fig. 3 である. Fig. 2 に示される幼児の DOL の 非変化対について，第 1 試行と第 2 対試行の正反度率の 差を $\chi^{2}$ 検定にかけたところ有意差は見出されなかっ

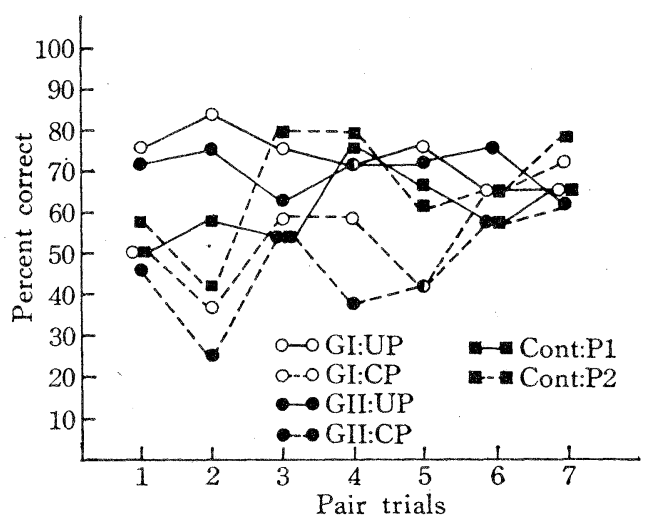

FIG. 4. Learning functions of preschoolers of NRS-changed, NRS-unchanged, and controls. For controls, pair trial refers to successive presentations of both stimulus pairs.

Note. G I : Group I. G II : Group II. UP : Unchanged pair. CP : Changed pair. Cont : Controls. P 1 : Pair 1 (corresponding to the unchanged pair in Groups I and II). P 2 : Pair 2 (corresponding to the changed pair in Groups I and II).

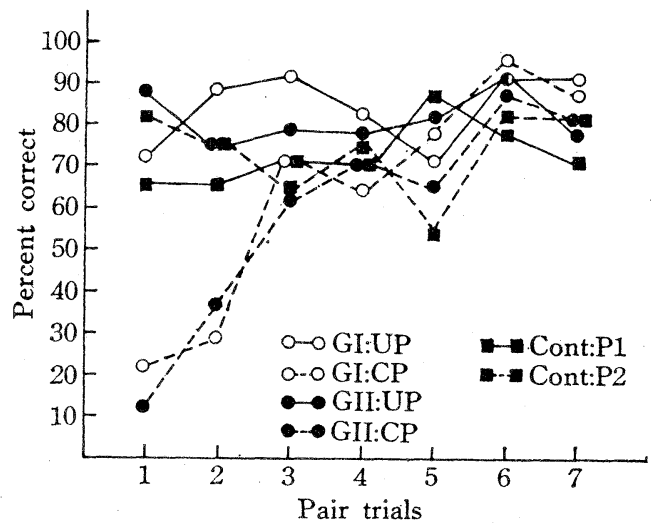

FIG. 5. Learning functions of primary school children of NRS-changed, NRS-unchanged, and controls. For controls, pair trial refers to successive presentations of both stimulus pairs.

Note. G I : Group I. G II : Group II. UP : Unchanged pair. CP : Changed pair. Cont : Controls. P 1 : Pair 1 (corresponding to the unchanged pair in Groups I and II). P 2 : Pair 2 (corresponding to the changed pair in Groups I and II). 
た.しかし，幼児の DOL 反応様式では試行につれて非

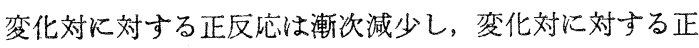
反応は渐次增加している傾向がみられる，各対試行に拉 ける非変化対と变化対汇対する正反応（人数）の開きを $\chi^{2}$ 検定したところ，第 1 対試行 $\left(\chi^{2}{ }_{(1)}=19.00, p<.001\right)$ と第 2 対試行 $\left(\chi^{2}{ }_{(1)}=7.35, p<.01\right)$ では共に有意差が 見出され，第 3 対試行 $\left(\chi^{2}(1)=3.52, p<.10\right)$ と第 4 対 試行 $\left(\chi^{2}(1)=3.20, p<.10\right)$ でも開きが大きく, それ以 後は次第に開きが小さくなっている。一方 IOL 反応様 式の非変化対と変化対の正反応の開きは, DOL 反応様 式の場合に比較して当然小さく，乙かもかなり不規則で ある.Fig. 3 亿示される児童の DOL の非変化対につい て, 第 1 対試行と第 2 対試行の正反応率の差を $\chi^{2}$ 検定 にかけをところ有意差が見出された $\left(\chi^{2}{ }_{(1)}=4.56, p<\right.$ .05)。その後はほぼ同じ水準を保ち, 逆に変化対への正 反応は, 幼児の場合とは異なり急激に增加している. 幼 児の場合と同様，各対試行に括沙る開きを $\chi^{2}$ 検定した ところ, 第 1 対試行 $\left(\chi^{2}(1)=35.00, p<.001\right)$ と第 2 対試 行 $\left(\chi^{2}{ }_{(1)}=13.44, p<.001\right)$ では共に有意差が見出され たが，第 3 対試行以後は急激に開きが小さくなり，幼児 群のそれよりるさらにその開きがちがまっている。一方 IOL 反応様式の非変化対と変化対の開きは, DOL 反応 様式の場合に比較して当然小さく，乙か子幼児の場合よ りる規則的にしか子急激に上昇する傾向を示している。

次に DOL 反応様式と IOL 反応様式に分けないで, 変化対と非変化対汶対する正反応率を全体として比較し たものが Fig. 4 と Fig. 5 に示されている. 児童が幼児

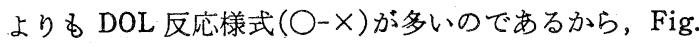
4 と Fig. 5 からも明らなように, 2 つの対の間の開き は当然児童では大きく，幼児では小さい。幼児 (Fig. 4) の第 I 群と第群をこみにして第 1 対試行の非変化対と 変化対の開きを $\chi^{2}$ 検定したところ, 有意差は見出され なかった $\left(\chi^{2}{ }_{(1)}=2.48\right)$ が，児童 (Fig. 5) の第 1 対試 行では有意差が見出された $\left(\chi^{2}{ }_{(1)}=19.57, p<.001\right)$. な怙統制群についてみると，2 つの刺激対の間の開きは 小さいことが見出された。

通常の NRS においては, 先行学習の学習規準に到達 するまで訓練が行なわれ，その後移行学習に移るが，本 実験は観察学習であるから, 先行学習は MO の反応を観 察し，移行学習においてはじめて OB が反応する期間と

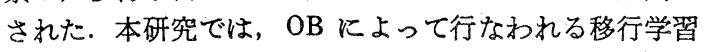
の初期, とくに第 1 試行と第 2 試行に挌ける正・誤反応 の型によって観察学習の反応様式がとらえられた. その 結果, Table 2 から明らかなよらK, 幼児では観察試行 数が少ない場合, DOL 反応様式 $(\bigcirc-x)$ と IOL 反応様 式( $\bigcirc-O, x-x)$ の 2 つ反応様式が等しく出現してい
る.このことから, 第 1 の仮説の前半部分は検証され たといえよう.しかし, 観察試行数の多い第 II 群は, “観察期間が長くそのため各刺激対一報酬関係が依存的に 学習されるために, 第 I 群に比較して DOL 反応様式の 出現が多い”とした第 1 の仮説の後半部分は検証されず, 観察試行数の多少にかかわらず上記の 2 つの反応梯式が ほぼ同じ比率で出現した。

児童では, Table 2 から明らかなように, 観察試行数 が少ない群（第I群）でも多い群（第II群）でも IOL 反応様式よりも DOL 反応様式が多く出現している. こ のことから第 2 の仮説の前半部分は検証されたといえ

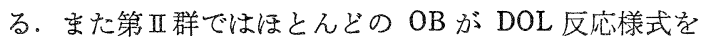
示しているので, 第 2 の仮説の後半部分, すなわち “観 察期間が長ければ，そのために各刺激対一報酬関係が一 層依存的汇学習される”といら点も検証されたといえ る.

幼児では観察試行数の効果が認められなかったが，そ の理由の 1 つとして，MO の反応をかなり多く観察する とかえって反応が混乱するのではないかといらことが考 えられる. 本実験で用いられた刺激対と全く同じものが 用いられた利島・祐宗 (1973) の場合にも, 認知・媒介 的反応様式とみられた次元内移行についてみると，この 反応様式が 30 回群と 10 回群とではほぼ同じ比率で出現 し, そして 20 回群で最す多く出現している. 利島・祐 宗 (1973) と本実験とでは同じ刺激対が用いられたとは いえ, 前者は選択移行学習事態であり, 本実験は NRS 事態である. しかる各反応様式としてとらえられた $O B$ の反応自体が手続き上相互に異なっているので, これら を同じレベルで比較することはできないであろう。しか 乙両研究結果から, 幼児は児童とは異なり, この種の刺 激対で 30 回の観察試行を行ならと, かえって, OB の区 応混乱が生じるのではないかといらことが示唆される ように思われる. もし本実験に物いて 20 回の観察試行 群を設けていたならば, この点が一層明白になったであ ろうと考觉られる。

次に本研究の第 3 の目的飞沿って, DOL 反応様式と IOL 反応椂式を示した OB が, 非変化対と変化対に対 してどのような反応を示したかを年龄別・反応様式別に 分析した. この分析は, 観察学習とは無関係に最初 Tighe, Glick, \& Cole (1971) によってなされた非変化対 之変化対に対する反応分析，すなわち下位問題分析にな らって行なったるのである (Fig. 2 と Fig. 3 を参照). 幼児と児童とではその様相がかなり異なっていることを 明らかにしている. 幼児の DOL 反応様式の非変化につ いて, 第 1 対試行と第 2 対試行の正反応率の間に有意差 は見出されなかった。 IOL の両対についてみると,やや 複雑な様相を示している. したがって, 幼児にかんして は, 当初の第 3 の仮説は検証されたとはい充ないにして 
子，第 3 対試行以後の非変化対飞対する正反応率をるる と漸次減少している点からみて, DOL 反応椂式と類別 されたものが “独立的”な観察学習をしたとするよりる “依存的”な観察学習をしたと推測することの方がより 適切なよらに考兄られる。児童についてみると，第 2 対 試行に招いて, 非変化対注対与る正反応率は第 1 対試行 のそれより有意減少している，IOLについてみると， 予測ぞ扮り，両対の開きは小さ，正反応率は漸次上昇 している。したがって, 児童にかんする第 3 の仮説は検 証されたといえよう。

幼児で DOL 反応様式を示した 19 名の OB のらちの 5 名は, NRS 過程全体を通じて非変化対比対しては常 飞正反応を，变化対に対しては常に誤反応を示してい る. したがって，Fig. 2 の DOL 反応様式の非変化対と 变化対の間の開きが大きい，一方，DOL 反応様式を示 した児童 35 名のうち, 非变化対に対しては常に正反応 を，変化対汶対しては常汇誤反応を示したものは皆無で あった。したがって児童の場合には，非変化対と変化対 の開さは小さい (Fig. 3 参照)。このように, 同じ DOL 反応様式でも幼児と児童とでは, 観察内容の移行学習へ の転移能力といら点で差異があるように思われる。つま り，児童は移行学習の比較的初期に叔いて，かなりはや く独自学習に移りらるが, 幼児ではそれが困難な者がい るといえよう．上述の幼児の 5 名は，2 つの刺激対を独 立的に観察していたのではなくて，2 つの刺激対を依存 的に観察していたのであるが，移行事態に入ってそれが いわば固執され，はやく転移汇まで至らなかったと考兄 ることも可能であろう。このような観点から, 本実験事 態の場合には，DOL 反応様式を示寸幼児の中に，は中 く独自学習に移り得る OB とそれが困難な OB とがい るといらこともできよう. 幼児が児童にくらべて, 観察 時の反応を固執する傾向をすつ, 換言すれば独自学習に 移るのが比較的困難であるということは, 变化対に対す る正反応率が児童にくらべて低いことと対応している (Fig. 2 と Fig. 3 を参照). このように下位問題分析に よって両反応様式の類別の適切さならびに観察内容が第 3試行以後の NRS にどのような効果を呿よぼすかの問 題を比較的詳細に検討することができたように思われ る.

次に，児童では DOL 反応様式が IOL 反応様式より る多く出現するとした第 2 の仮説が検証されたが，この ことはとりもな招さず移行初期法和ける OB の非変化対 と変化対に対する正反応率の開きが大きいことを意味し ている. 事実, 反応様式別ではなく, 幼児と児童に打け る群ごとの下位問題分析の 結果 (Fig. 4 と Fig. 5 を参 照）から一見してわかるように，児童ではどの群でも開 きが大きく，幼児ではどの群でも開きが小さい，しかる その後の対試行の成績をみても, 児童では幼児にくらべ
て非変化対付対する正反応率が急激に上昇して括り， NRS 全体を通じて児童が優位な成績を掠さめているこ とを示している，2つの刺激対汶する統制群 の反応 は, 観察経験がないのであるから, Fig. 4 と Fig. 5 か らわかるよらに, 児童も幼児も雨刺激対の開きは当然僅 少である、ただ児童の方が幼览にくらべて，すでに試行 の初期から正反応率が高いこともらかが党る、本実験は NRS 事態であるから，観察時の各刺激対の正負と NRS での各刺激対の正負は全く同一ではなく1つの対に限っ て変化して扣り，いわば転移学習事態である。一方統制 群の被験者にとっては, 本実験はいわば大ささ(大・小) または形（円・三角形）の升別学習事態に相当してい る.このような場合でも, 実験群・統制群を問わず，幼 児・児童ともNRS 過程全体を通じて注涪同じような成 績を招さぬていることがわかる。

Fein (1973) は，幼児・児童を用いた 4 選択弁別事態 飞打いて，模倣行動に和上ぼすCA 之報酬の効果につい て研究し，その中で児童が幼児にくらべて模做行動を 有意に少なく示すことを見出している．Fein による と, 認知的能力の低い幼児は, 成人の行動を注意深く 観察し，それを模做することが問題解決をより成功に導 くことを知っている，すなわち外部指向的である，一方 認知的に成熟した児童では，自分自身が行なった解決行 動によって成功経験をるつようになり，単なる模做行動 を積極的に回避する傾向が強くなるとしている（外部指 向的態度の放棄). われわれの本実験では, 最初の 2 試 行つまり反応様式としてとらえたるのが模做行動にあた るとすれば，児童が幼児より模倣行動が少ないとする Fein の結果とは一致しない上うに思われる。われわれ の研究で,たとえば DOL 反応様式 $(O-X)$ を示した者 をとりあげてみると，児童は 35 名で幼児は19名であり， 前者が有意に多く模倣行動を示しているといえよう $\left(\chi^{2}{ }_{(1)}=4.74 . \quad p<.05\right)$. 幼児は外部指向的であり, 児童

4 本研究の計画にあたって, 最初観察々非観察の効果 を比較するため観察群（実験群）と並んで次の 2 つの統 制群の設定が検討された. 1 つは観察を行なわないで独 自の先行弁別学習を行なわせ，後に移行学習を行なわせ 万群，他は観察も独自の先行弁別学習も行なわせない で, 移行学習（ただしこの群の被験者にとっては独自な 弁別学習に相当する）の及を行なわせる群であった。し かし本研究は，とくにこうした統制群を設定しなくてる 本研究に据ける目的を十分達成しらると考光, 分析にあ たって以下のような点を検討するため, 後者のみが採用 された。すなわち，この統制群の成績は，第 1 対試行 （すなわち実験群にとっては非変化対と变化対に相当す る）に和ける正反応率はほぼ50\%になるである5。し たがって下位問題分析の第 1 対試行における両者の開き は，実験群のそれにくらべてほとんどないであろうとい らことが期待された。 
は外部指向的態度を放棄する傾向があるとする Fein の 考え方は，われわれの実験結果に一見似た点がある。す なわち, 本実験の NRS 過程の第 3 試行以後の学習曲線 (Fig. 2 と Fig. 3 の DOL 反応様式の曲線を参照) をみ ると, 幼児では扣そらく転移能力の不足, すなわち観察 内容を固執する傾向が強いために，変化対に対する誤反 応が最後まで続く者がいるが，反面児童ではそのような 反応が全くみられず, 変化対に対する正反応率は急激に 高くなっているからである、しかし Fein の研究では 4 選択升別学習事態と部分強化事態が採用されているか ら，当然 OB は MO の行動を回避する傾向がうまれて くるであろう。しかしわれわれの 2 選択・連続強化の NRS 事態ではそのような傾向がうまれてくる余地がな いといってもよからら. したがって，Fein の研究結果 を本実験結果と同列に論じることには無理があるように 思われる。

最後に，問題のところでも述べたように，本研究での DOL 反応様式が多分に認知・媒介的な面をもち, IOL 反応様式が単純・非媒介的な面をるつと考えるならば, 児童は幼児にくらべて単純・非某介的に観察し反応する よりる, 認知・媒介的に観察し反応する傾向がより顕著 であるといらことがでさようわわれわれは，DOL 反応 様式 $(\bigcirc-\times)$ を次元性媒介に基づくものであると考える が，実験操作上その点を十分明確にすることが困難な面 ああるので, 本研究ではむしろ“依存的”反応様式とい ら用語を用いている。一方，この○ーメ反応は必ずしも次 元を抽出しなくても, 両刺激対を共に（いわば“独立的” に）観察学習した結果として出現しうるといら考え方も 可能であるかもしれないしかし，そらであるとすれ ば，先にみてきたように，下位問題分析に拉いて DOL の非変化対に対する正反応率が变化対に対する反応の結 果に影響をらけて減少するというような現象は生じにく いと考えられよう。しかし，この点については，今後一 層十分な検討がなされるべきであるう。

\section{要約}

本研究の第 1 の主要な目的は, 非逆転移行学習 (NRS) の範例に準拠した観察学習に特いて，幼児では観察試行 数が少ない場合, 独立的(IOL)反応様式（非変化対が提 示される第 1 試行は正反応で, 変化対が提示される第 2 試行は正反応：○一○；または共に誤反応：メーメ）と依 存的 (DOL) 反応様式（非変化対が提示される第 1 試行 は正反応で,変化対が提示される第 2 試行は誤反応：○一 ×） 2 つがほぼ同じ比率で出現するが，観察試行数が 多い群についてみると, 観察期間が長くそのため各刺激 対一報酬関係が依存的に学㖬されるため, IOL 反応様式よ りも DOL 反応様式がより多くあらわれるであららとい ら仮説を検証することである。第 2 の主要な目的は，認
知・媒介的に観察し反応する様式が優位を占める児童に おいては, 観察試行数が少ない群でも多い群です IOL 反応様式よりす DOL 反応様式がより多くあらわれる が，多い群についてみると，観察期間が長くそのため各 刺激対一報酬関係が一層依存的に学習されるため, IOL 反 応様式は極めて少なく，ほとんど DOL 反応様式のみが 出現するであろらという仮説を検証することである。第 3 の目的は, NRS の全過程を年齢別に変化対と非変化対 に分けて正反応率をみる下位問題分析を行なうことによ って, 両反応様式の類別の適切さならびに両反応様式の その後の独自学習に就よぼす効果を明らかにすることで ある。

課題は大きさ（大・小）と形（円・三角形）の2次元 2 価からなる刺激対が用いられ，NRS に準拠した実験 が行なわれた. 先行弁別学習事態では MO の行なう示 範を OB が観察し，それに引き続く非逆転移行事態（テ スト）に特いてはじめて OBの反応が要請された. 先行 弁別事態での MO の示範回数としては，幼児・览童と

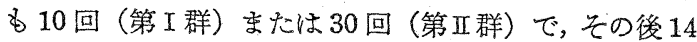
回の NRS 試行が行なわれた。幼児・児童とも統制群に は，MO の示範を観察しないで害験群の行なう14 回の NRS に相当する部分の学習が課せられた. 被験者は 5 , 6 歳の幼児 72 名（男子 36 名，女子 36 名）と 8,9 歳の 児童 72 名（男子 36 名，女子 36 名）であった，大学生 8 名が MO として参加した.

主要な結果は次の通りである.

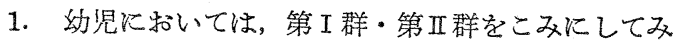
ると，DOL 反応様式と IOL 反応様式の 2 つの反応様式 が出現し，両者の出現頻数の間に有意差は見出されなか

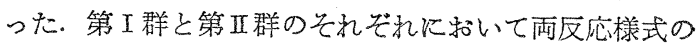
出現頻数の間に有意差は見出されなかった. したがって このことから，第1の仮説の前半部分は検証されたが， 観察試行数の効果に関する第 1 の仮説の後半部分は検証 されなかった。

2. 児童に塥いては，観察試行数が少ない群(第 I 群) でも多い群（第II群）でも，IOL 反応様式よりも ○(DOL) 反応様式が有意に多く出現している。このこと

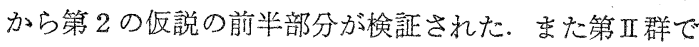
はほとんどの OB が DOL 反応様式を示した。このこ とから第 2 の仮説の後半部分す検証された.

3. 第I群・第II群をこみにして幼児の DOL 反応様 式を示した者の下位問題分析をしてみると，第1対試行 と第 2 対試行に和りる非変化対に対する正反応率の間に 有意差が見出されなかった。 しかしそれ以後正反応率 は漸次減少し，変化対比する正反应率は漸次上昇する ことが見出された。これらのことから，当初の第3の仮 説は検証されたとはいえないにしても，DOL 反応様式 と類別されたものが “独立的”な観察学習をしたという 
よりも“依存的”な観察学習をしたと推測された。変化 対に対する正反応は漸次増加することが見出された。同 様に群をこみにして，児童のDOL 反応様式を示した者 についてみると, 試行につれて非変化対に対する正反応 は最初少し減少するがその後はほぼ同じ水準を保ら，逆 に変化対に対する正反応は，幼児の場合とは異なり急激 に増加することが見出された。このことから児童に関す る第 3 の仮説は検証された，幼児・児童にも，IOL 反応 様式を示した者の両刺激対の開きは, 全試行を通じて小 さいことがわかった。

4. 幼児・児童とも, DOL 反応様式と IOL 反応様式 に分けないで下位問題分析をしてみると，NRS の初期 に持いては, 幼児では各群とも非变化対と変化対の間の 開きが小さく，览童では大きいことか゚見出された。統制 群では，2 つの刺激対の間の開きは小さいことがわかっ た.

5. DOL 反応様式は認知・媒介的なるのとして，ま た IOL 反応様式は単純・非媒介的なるのとして考えら
れるのではないかといらことが示唆された。

\section{引用 文 献}

Fein, G.G. 1973 The effect of chronological age and model reward on imitative behavior. Developmental Psychology, 9, 283-289.

祐宗省三 1973 幼览の弁別学習に打ける刺激特性の分 析一一色・形次元を中心として—— 心理学研究，44， $328-333$.

祐宗省三・利島 保 1973 幼児の観察学習に括けるモ デルおよび観察者の反応パタンの分析心理学研究， 44, $17-23$.

Tighe, T. J., Glick, J., \& Cole, M. 1971 Subproblem analysis of discrimination shift learning. Psychonomic Science, 24, 159-160.

利島 保・祐宗省三 1973 幼児の観察学習における反 応㥞式の分析 心理学研究, 44, 261-267.

-1974. 8. 8. 受稿—

\section{SUMMARY}

The purpose of the present study is to provide data on the observational learning modes from the developmental point of view. The first hypothesis consists of the following two statements. First, both independent observational-learning mode (IOL) and dependent observational-learning mode (DOL) would be found in the nonreversal shift (NRS) of preschool children. Secondly, the more an observer (OB) observes the original discrimination of NRS demonstrated by a model (MO), the more DOL would occur because of dependent observational-learning of the relationships between each stimulus pair and reward. Both DOL and IOL are defined in terms of correct $(\bigcirc)$ or incorrect $(X)$ responses on the first (unchanged pair) and the second (changed pair) trials of NRS. The $\bigcirc-\times$ type is designated as DOL, and both $\bigcirc-O$ and $x-x$ types are designated as IOL (see Table 2). The second hypothesis also consists of the following two statements. First, in school children, DOL would occur more than IOL regardless of the number of observational trials. Secondly, a large amount of observation of the original discrimination would lead to almost exclusive occurrence of DOL because of greater dependent observational-learning of the relationships between each stimulus pair and reward. The third hypothesis states that $\bigcirc-X$ does correspond to the "dependent" mode rather than the "independent" one. This will be tested by subproblem analyses of performance on trials with the unchanged and the changed pairs.

The $S$ s were 72 preschoolers and 72 school children. The orignal discrimination of NRS of two stimulus dimensions with two values each was demonstrated by an MO (see Fig. 1), and then an $O B$ was required to perform himself 14 NRS trials (test). The observational trials were 10 (Group I) and 30 (Group II) for each age group. Controls were reqired to perform the same 14 trials without preceding observation (see Table 1).

The main findings were as follows: in preschoolers the two observational-learning modes were found, as many $\bigcirc-x$ and $\bigcirc-\bigcirc$ and $X-X$ occurring in each group (see Table 2). Therefore, only the first statement of the first hypothesis was supported. In school children, $\bigcirc-X$ occurred more than $\bigcirc-\bigcirc$ and $x-x$ in each group. In Group II, $\bigcirc-x$ occurred almost exclusively, and $\mathrm{O}-\mathrm{O}$ and $x-x$ were almost nonexistent (see Table 2). Therefore, the second hypothesis was entirely supported. The subproblem analysis of DOL preschoolers on trials with the unchanged and 
the changed pairs revealed a marked difference in the learning of the two pairs with $S$ s exhibiting a slow, gradual decrement of correct choices on the unchanged pairs as the NRS progressed, and a slow, gradual increase of correct responses to the changed pair (see Fig. 2). Meanwhile, school children classified as DOL exhibited a sudden decrement of correct choices on the unchanged pair on the second pair-trial, and a sudden increment of correct choices on the changed pair on the same pairtrial (see Fig. 3). Thus, the third hypothsis concerning school children was entirely supported. It may be stated that the hypothesis concerning preschoolers was barely supported. It was suggested that DOL and IOL probably correspond to a "cognitive, mediational" mode and a "single, unmediational" one, respectively. 